\title{
Biodiversity of aquatic environments in a peri-urban Atlantic Forest protected remnant: a checklist
}

\author{
Karine Matos Magalhães ${ }^{I *}$, Maria Cecília Santana de Lima ${ }^{1}$, Ednilza Maranhão Santos ${ }^{I}$, Jozélia Maria de \\ Sousa Correia ${ }^{1}$ \& Ana Carolina Borges Lins e Silva ${ }^{1}$ \\ ${ }^{1}$ Universidade Federal Rural de Pernambuco, Departamento de Biologia, Recife, PE, Brasil \\ *Corresponding author: Karine Matos Magalhães, e-mail: magalhaeskm@gmail.com
}

\begin{abstract}
MAGALHÃES K.M., LIMA M.C.S., SANTOS E.M., CORREIA J.M.S., SILVAA.C.B.L. Biodiversity of aquatic environments in a peri-urban Atlantic Forest protected remnant: a checklist. Biota Neotropica. 19(4): e20190761. http://dx.doi.org/10.1590/1676-0611-BN-2019-0761
\end{abstract}

\begin{abstract}
We present a checklist for the aquatic biodiversity from two reservoirs within a PPBio (Biodiversity Research Program) site in a peri-urban forest fragment, the Dois Irmãos State Park (PEDI), in Pernambuco, Brazil. We obtained the data via extensive field collection and information from a specialized literature survey. We recorded 397 species in 156 families; the animal was the most abundant group ( 140 species) followed by fungi taxa (103), periphyton (69), aquatic macrophytes (44), and terrestrial plants in flooded areas (41). This review reflects different sample efforts toward selected groups and allows the definition of a long-term protocol for guiding new research based on the identified knowledge gaps revealed. Future ecological research should address the influence of the trophic state of the reservoirs, as well as the effects of competitive exclusion and predation on the long-term viability of the local diversity.
\end{abstract}

Keywords: PPBio, PEDI site, Aquatic macrophytes, Fungi, Aquatic Fauna.

\section{Biodiversidade de ambientes aquáticos em remanescente protegido da Mata Atlântica periurbana: um checklist}

\begin{abstract}
Resumo: Apresentamos uma lista da biodiversidade aquática de dois reservatórios em um sítio do PPBio (Programa de Pesquisa em Biodiversidade) em um fragmento de floresta peri-urbana, o Parque Estadual Dois Irmãos (PEDI), em Pernambuco, Brasil. Obtivemos os dados através de extensa coleta de campo e informações de pesquisa bibliográfica especializada. Registramos 397 espécies em 156 famílias; os animais foram o grupo mais abundante (140 espécies), seguido pelos fungos (103), perifíton (69), macrófitas aquáticas (44) e plantas terrestres em áreas alagadas (41). Esta revisão reflete diferentes esforços de amostra para grupos selecionados e permite a definição de um protocolo de longo prazo para orientar novas pesquisas com base nas lacunas de conhecimento identificadas. Pesquisas ecológicas futuras devem abordar a influência do estado trófico dos reservatórios, bem como os efeitos da exclusão competitiva e predação na viabilidade a longo prazo da diversidade local.
\end{abstract}

Palavras-chave: PPBio, site PEDI, macrófitas aquáticas, fungos, fauna aquática.

\section{Introduction}

Continental aquatic ecosystems have been experiencing unprecedented disturbances in recent decades (Saunders et al. 2002) and are among the most threatened ecosystems in the world (Dudgeon et al. 2006) with $65 \%$ of aquatic habitats threatened (Vörösmarty et al. 2010). Changes in the flow regime of water bodies negatively impact the primary structure of river systems and wetlands (Bunn \& Arthington 2002). Excessive withdrawal of water for agricultural, industrial (Szollosi-Nagy et al. 1998) and urban uses (Urban et al. 2006) may lead to water shortages in coming years (Szollosi-Nagy et al. 1998).

As a result, aquatic biodiversity is under pressure (JanuchowskiHartley et al. 2016), leading to both population decline and range reduction of freshwater species (Dudgeon et al. 2006). Between 1990 and 2010, 123 freshwater animal species were considered to be extinct in North America alone (Ricciardi \& Rasmussen 1999) while 10,000 to 20,000 freshwater species are estimated to be under risk of extinction or already extinct worldwide (Vörösmarty et al. 2010). Knowledge of biodiversity is insufficient for tropical regions where a high number of species are distributed, but species loss rates have still not been accurately calculated (Dudgeon et al. 2006).

In addition to local threats to biodiversity, there are also global impacts such as nitrogen deposition, changes in rainfall patterns, and global warming (Dudgeon et al. 2006). Long-term monitoring programs are essential for evaluating possible changes in the composition and abundance of biodiversity and in the main abiotic factors that affect 
the dynamics of populations and habitats (Pezzini et al. 2012). With this goal in mind, the Biodiversity Research Program (PPBio) was created in 2004, aiming at intensifying studies on biodiversity in Brazil and integrating research findings and actions for various targets, including environmental management. A PPBio site was established in Pernambuco in 2013 at the Dois Irmãos State Park (PEDI) where there are two artificial water bodies, Prata and Dois Irmãos reservoirs.

An initial diagnosis of the existing biodiversity is required to subsidize and initiate long-term studies and monitoring, identify knowledge gaps, and guide management actions. Thus, the objective of this work is to present a checklist of the up-to-date aquatic biodiversity of the reservoirs in order to support conservation actions and a subsequent long-term research planning for this area.

\section{Material and Methods}

\section{Study site}

The PEDI comprises 1157.44 hectares of forest which 384.42 hectares are mature. It is located in the metropolitan region of Recife ( $8^{\circ} 04^{\prime} 03$ " S/34 55' 00" W; Figure 1), Pernambuco, Northeast Brazil. The climate is tropical As' (Alvares et al. 2013) with a mean annual precipitation of $2460 \mathrm{~mm}$ and an average monthly temperature of $23^{\circ} \mathrm{C}$ (Silvestre \& Carvalho 1998). The dry period occurs between September and February, and the rainy period is from March to August (Coutinho et al. 1998).

There are four reservoirs (Dentro, Dois Irmãos, Meio, and Prata) in the mature forest portion of the PEDI-all built in the first half of the nineteenth century to supply water to the city of Recife (Silvestre $\&$ Carvalho, 1998). Of these four water bodies, two occur within the grid of the PPBio-PEDI monitoring site. The Dois Irmãos reservoir $\left(8^{\circ} 00^{\prime} 42.6^{\prime \prime} \mathrm{S} / 34^{\circ} 56^{\prime} 48.2^{\prime \prime} \mathrm{W}\right)$ is a eutrophic reservoir with 12 hectares and covered with floating macrophytes. It is situated within an intensely managed area of the Park, where there is a zoo, and is surrounded by roads, services, and building facilities for visitors and recreational uses (Silvestre \& Carvalho 1998, Thomas \& Middleton 2003). The Prata reservoir ( $8^{\circ} 00^{\prime} 16.2^{\prime}$ ' S/34 $57^{\circ} 00.8^{\prime}$ W) covers 1.7 hectares and is oligotrophic. It is surrounded by the primitive or core zone of the park, where natural processes dominate, and the best forest values are preserved. Despite this, the reservoir is used for public water supply in the metropolitan region of Recife (Silvestre \& Carvalho 1998).

\section{Data collection}

We obtained data through field collection and literature survey, which initially included scientific papers published in journals with an editorial board. As a starting point for the survey, we searched through the "Portal de Periódicos Capes/MEC", a free access Brazilian search tool for indexed journals and scientific literature provided by the Ministry of Education (MEC), containing more the 45,000 available journals, 130 reference bases, books and encyclopedias. We applied the following search terms in advanced search options, in combinations of taxonomic group (i) AND the target location (ii), in English and Portuguese: (i) biodiversity (fungi; aquatic macrophyte; ichthyofauna, fish; microalgae, periphyton, phytoplankton; herpetofauna; mastofauna; birds; zooplankton, Cladocera, Copepoda, Rotifera; fauna; flora); and (ii) Dois Irmãos State Park (PEDI), Prata Reservoir and Dois Irmãos Reservoir. Since this initial search returned only seven records, we expanded the search to encompass grey literature, including book chapters, simple summaries, expanded abstracts published in meetings and congresses, monographs, theses, and dissertations in addition to

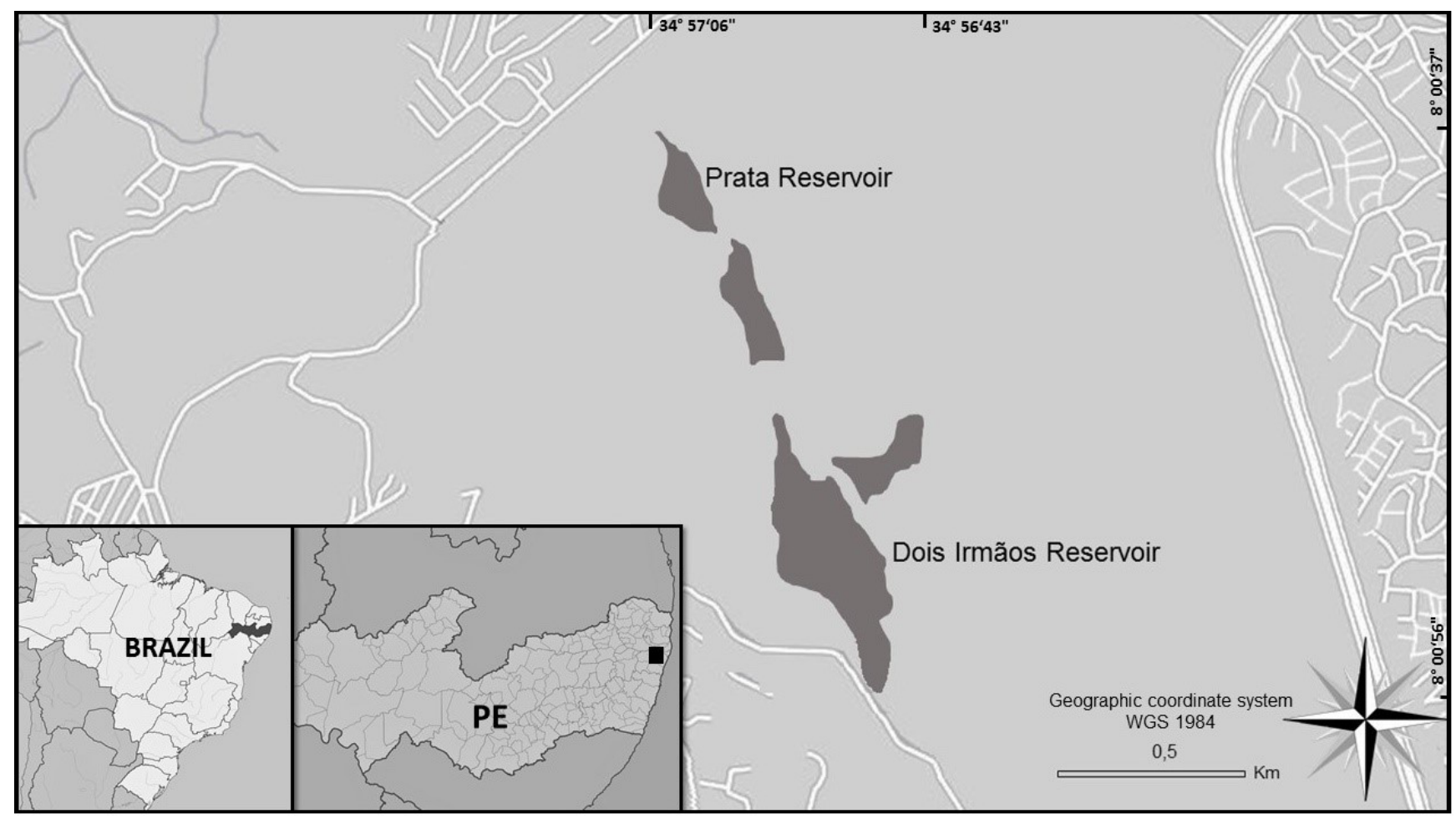

Figure 1. Location of the studied areas in the Dois Irmãos State Park (PEDI), Recife, Pernambuco, Brazil. 
technical reports available online. This search returned a total of 22 records from 1993 to 2019. The database WikiAves (2008) was also searched for bird occurrences, and personal observations from the group Birdwatchers of Pernambuco (OAP) were included.

We compiled the lists of species per taxonomic groups and habits: plants were categorized as macrophytes, terrestrial herbs, shrubs or periphyton. The identities were checked with specialized literature for each group. For plant species, we used the Flora do Brasil (2018); for birds, Piacentini et al. (2015); reptiles and amphibians, Pereira et al. (2013), Pereira et al. (2016) and Santos et al. (2017); for fish species, Fish Base (Froese \& Pauly 2018); and for mammal species, Paglia et al. (2012).

Whenever possible, species occurrences were assigned to the Prata or Dois Irmãos reservoir. There were cases, however, when surveys were carried out in two, three, or all water bodies in the forest with no distinct sample points. In these cases, species lists were included if the Prata and Dois Irmãos reservoirs were cited as the study area. We also incorporated information on species sampled by the PPBio team through fieldwork or querying local informants.

We assessed the conservation status of each species on the Red List of the International Union for Conservation of Nature (IUCN 2018) and on the Brazilian List of Threatened Species for Animals (MINISTÉRIO 2014) and plants (MARTINELLI 2013). The biogeographic origin of each species (native or non-native) was examined. Non-native species were also searched if the species had been classified as an invasive species according to the invasive non-native species database I3N Brasil (Instituto Hórus de Desenvolvimento e Conservação Ambiental 2018) as well as the Global Invasive Species Database (GISD) managed by the Invasive Species Specialist Group (ISSG) of the International Union for Conservation of Nature (IUCN 2018).

\section{Results}

We registered 397 species distributed in 156 families and 82 orders for the aquatic biodiversity of the Dois Irmãos and Prata reservoirs (Figure 2). The animal was the most abundant group with 140 species divided into herpetofauna (42 species, 12 families, Table S1), Rotifera (40 species, 12 families, Table S1), birds ( 23 species, 09 families, Table $\mathrm{S} 1)$, Cladocera (18 species, 04 families, Table S1), fish (15 species, 10 families, Table S1), and mammals (02 species, 02 families, Table S1). Fungi represented $28.93 \%$ of the local richness (103 species in 46 families; Table S2) followed by periphyton $(19.38 \%, 69$ species in 23 families; Table S3), aquatic macrophytes (44 species in 17 families, Table S4), terrestrial plants (41 species, 23 families, Table S4).

Although much smaller in size, the Prata Reservoir held a higher number of exclusive occurrences: 204 species against 94 in the Dois Irmãos; however, this reflects a bias towards the sampling of the less impacted and more conserved Prata reservoir. Research about Fungi and periphyton, for instance, are exclusive to the Prata water body although most of the studies in the PEDI were performed in both reservoirs $(36.36 \%)$ or on the Dois Irmãos reservoir $(36.36 \%)$. Fauna groups were sampled in both reservoirs and were less selective.

The two reservoirs have no plant (terrestrial, macrophytes, periphyton) or fungi species under risk of extinction according to the IUCN Red List. Of the total plants accessed, most are not evaluated, and 17 are categorized as of Least Concern (LC). On the Brazilian

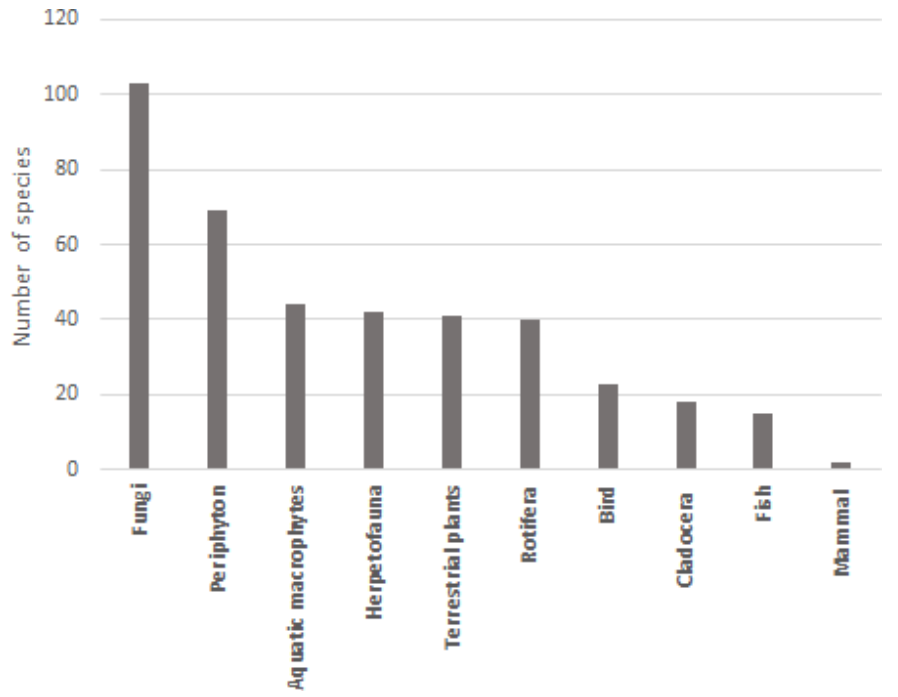

Figure 2. The number of species in different taxonomic groups recorded for the aquatic biodiversity of Dois Irmãos and Prata reservoirs, Pernambuco, Brazil.

Red List for plant species, only six are included, but five are listed as LC and one as Data Deficient (DD). Among animal taxa, there are 62 species evaluated as LC on the IUCN Red List - mostly Anuran or Bird species. The neotropical river otter (Lontra longicaudis, Olfers, 1818) is near threatened (NT) on the IUCN list and Vulnerable in the Brazilian Atlantic Forest and the yellow-spotted river turtle (Podocnemis unifilis, Troschel, 1948) is considered vulnerable and near threatened (NT) for the same lists, respectively. In addition, three species were found to be endemic, although not restricted to the region or the biome: two plants (Rolandra fruticosa - endemic to North and Northeast Brazil - and Homolepis aturensis - endemic to North, Northeast and Southeast Brazil), and a mammal (Hydrochoerus hydrochaeris - endemic to South America east of the Andes).

Regarding the origin, there were six fungi, 13 plant taxa, and 15 animal species listed as non-native in the country or in the region. These include six potential invaders: the two aquatic herbs Vallisneria americana (Hydrocharitaceae) and Nymphoides indica (Menyanthaceae), and the terrestrial plants Lantana camara (Verbenaceae), Urochloa sp. (Poaceae), Nephrolepis cordifolia (Davalliaceae), and Pteris vittata (Pteridaceae). Eight species are native to Brazil, but not native to the studied region. These include the aquatic Eichhornia crassipes (Pontederiaceae), an Amazonian taxon, noted as one of the worst aquatic weeds in the world. Of the 21 non-native plants, 16 are recorded only in the Dois Irmãos Reservoir while five occur only in the Prata, including two potential invaders.

Six species of fungi (Penicillium dipodomyis, Pseudopithomyces sacchari, Purpureocillium lilacinum, Talaromyces funiculosus, T. verruculosus and Trichoderma aureoviride) and ten species of fish are non-native. Among fish species, nine come from other water basins in Brazil (Astronotus ocellatus, Astyanax bimaculatus, Cichla ocellaris, Electrophorus electricus, Gymnotus omarorum, Hoplias malabaricus, Hypostomus affinis, Pterophyllum scalare, Serrasalmus rhombeus) and one from Africa and Israel (Oreochromis niloticus). Three of them are potentially invasive species (A. ocellatus, C. ocellaris and $O$. niloticus) with predatory behaviour. Four non-native species of reptiles (Trachemys dorbigni, T. scripta, Podocnemis expansa and 
P. unifilis) are recorded. The two Trachemys species, only found in the Dois Irmãos reservoir, are considered potential invaders with known ecological impacts in other areas due to higher competitive abilities and predator status.

\section{Discussion}

The water bodies had a reduced group diversity of fauna and flora, probably due to the minor amount of scientific work performed and published in this area. These data reinforce the importance of programs such as the PPBio that focuses on the formation of a reliable database, grants for studies on the biological community structure, and biodiversity knowledge (Pezzini et al. 2012). Although not much is known about the continental aquatic biota in general, this survey revealed that the list of aquatic fungi in PEDI comprises more than $27 \%$ of the total number of known species in Brazil (Rocha 2003).

The aquatic flora recorded for PEDI represents approximately $22 \%$ of the aquatic biodiversity registered for the Northeastern Brazilian area (Moura-Junior et al. 2013). Aquatic flora has been a topic of recent studies due to its important link with water quality. The presence of the two invasive species and eutrophication indicators Eichhornia crassipes (Holm.) Solms and Salvinia auriculata Aubl. (Barreto et al. 2000) is a matter of serious concern as these species potentially have adverse effects not only on the aquatic biodiversity functioning, but can also prevent the use of the reservoir for leisure activities and offer favourable environments for disease vectors (Pedralli 2003).

The neotropical river otter is listed as "near threatened" but has a wide distribution. It can be found in rivers and streams (Kasper et al. 2004) and is a bioindicator for these environments because of its sensitivity to pollution. It is considered "vulnerable" in the Atlantic Forest biome due to extreme habitat degradation and susceptible to regional extinction within the next 50 years (Rodrigues et al. 2013). These animals are frequently hunted due to commercial interest on their skin or by fishers and fish farmers due to predation in fish farming tanks (Quadros 2009). Other activities can contribute to the decline of this species, such as fish introduction, deforestation, dredging, metals, and contamination by pesticides (Quadros 2009). Some of these impacts have already been observed in PEDI, especially the introduction of non-native fishes.

The introduction of non-native species to natural ecosystems represents one of the greatest threats to biological diversity on the planet (Simberloff 2003). In PEDI, we have recorded introduced speciesmostly fish species, with particular attention to Cichla ocellaris (Bloch $\&$ Schneider, 1801) and Oreochromis niloticus (Linnaeus, 1758). The former species is popularly known as tucunaré, originated from the Amazon basin. This species has an aggressive behaviour and preys on other fish species (Pelicice \& Agostinho 2009). The latter species, also known as tilápia, is omnivorous, with high reproductive efficiency, and is adaptable to environmental variability. It can increase water turbidity and lead to a considerable increase in phytoplankton biomass and abundance of cyanobacteria leading to adverse effects on water quality (Starling et al. 2002). In other reservoirs in Pernambuco (Lazzaro et al. 2003), there are already economic losses recorded due to increased costs for water treatment intended for public supply.
In general, most studies indicate that for conservation policy, including protection, restoration and management, all sizes of water bodies are important, as a set of small size ponds may contain higher conservation value that large ponds of the same size (Oertli et al. 2002, Scheffer et al. 2006), thus the diversity of aquatic habitats at PEDI is essential to biodiversity maintenance. Our findings suggest that studies on different biodiversity groups are still needed - particularly for wild fauna. Ecological questions on these studies should address the influence of the trophic state of the reservoirs in determining the composition of biodiversity. These efforts should also consider the effects of nonnative species on the long-term viability of local diversity, particularly concerning competitive exclusion and predation.

\section{Supplementary material}

The following online material is available for this article:

Table S1 - List of species of fauna identified at Prata and Dois Irmãos reservoirs, Pernambuco, Brazil.

Table S2 - List of species of fungi identified at Prata reservoir, Pernambuco, Brazil.

Table S3 - List of species of periphyton identified at Prata and Dois Irmãos reservoirs, Pernambuco, Brazil.

Table S4 - List of species of plants identified at Prata and Dois Irmãos reservoirs, Pernambuco, Brazil.

\section{Acknowledgements}

The authors would like to thank the PPBio Mata Atlântica Programme (23082.009572/201581), in the name of Helena de Godoy Bergallo and to the Dois Irmãos State Park authorities for the support.

\section{Authors' contributions}

Karine Matos Magalhães: Formulated the idea. Correia performed the field work and identification. All authors performed data analysis. Contributed to critical revision adding inteectual content and writing of the manuscript.

Maria Cecília Santana de Lima: Contributed to critical revision adding inteectual content and writing of the manuscript.

Ednilza Maranhão Santos: Performed the field work and identification. All authors performed data analysis.

Jozélia Maria de Sousa Correia: Performed the field work and identification. All authors performed data analysis.

Ana Carolina Borges Lins e Silva: Contributed to critical revision adding inteectual content and writing of the manuscript.

\section{Conflicts of interest}

The authors declare that they have no conflict of interest related to the publication of this manuscript.

\section{Data availability}

The data of this paper will follow the PPBio metadata politics. 


\section{References}

ALCÂNTARA, J.D.L.C. 2016. Influência de fatores ambientais na estruturação da comunidade de macrófitas aquáticas em um sistema de reservatórios em região tropical. Dissertação de mestrado, Universidade Federal Rural de Pernambuco, Recife.

ALVARES, C.A., STAPE, J.L., SENTELHAS, P.C., DE MORAES GONÇALVES, J.L. \& SPAROVEK, G. 2013. Koppen's climate classification map for Brazil. Meteorologische Zeitschrift. 22; 711-728. doi:10.1127/0941-2948/2013/0507.

ANTONEllo, A., RODRIGUES, A. D., SANTOS, J. S., MARCELINO, S. C., OLIVEIRA, L. H. V., ALENCAR, R. B., VIEIRA, V. L. A., SEVERI, W. \& ALBUQUERQUE, P. G. 1999. Ictiofauna do Açude Dois Irmãos. In: XI Congresso Brasileiro de Engenharia de Pesca - CONBEP, Olinda Pernambuco. Livro de Resumos, p. 148-148.

BARreto, R., CHARUdATtAN, R., POMELlA, A., HANADA, R. 2000. Biological control of neotropical aquatic weeds with fungi-Crop Protection, 19: 697-703.

BUNN, S. E. \& ARTHINGTON, A.H., 2002. Basic principles and ecological consequences of altered flow regimes for aquatic biodiversity. Environmental Management, 30: 492-507. DOI:10.1007/s00267-002-2737-0.

CAVALCANTI, M. D. S. \& MILANEZ, A. I. 2007. Hyphomycetes isolados da água e do solo da Reserva Florestal de Dois Irmãos, Recife, PE, Brasil. Acta Botanica Brasilica, 21(4): 857-862.

CORREIA, J. S.; MASCARENH AS, P. B.; SANTOS, E. M. 2015. Crocodilianos em remanescente de Mata Atlântica, nordeste do Brasil. In VII Congresso Brasileiro de Herpetologia, Gramado - Rio Grande do Sul.

COUTINHO, R.Q., LIMA-FILHO, M.F., SOUZA-NETO, J.B. \& SILVA, E.P. 1998. Características climáticas, geológicas, geomorfológicas e geotécnicas da Reseva Ecológica de Dois Irmãos. In Reserva Ecológica de Dois Irmãos: Estudos em um remanescente de Mata Atlântica em area urbana (Recife - Pernambuco - Brasil) (I.C. Machado, A. V. Lopes, \& J.C. Porto, eds). Editora Universitária da UFPE, Recife, p. 21-49.

CPRH - AGÊNCIA ESTADUAL DO MEIO AMBIENTE. 2012. Diagnóstico Socioecônomico e Ambiental. Plano de Manejo - Área de Proteção Ambiental-APAAldeia - Beberibe. Recife. Relatório Técnico. http://www. cprh.pe.gov.br/downloads/PM\%20AB1.pdf

DUDGEON, D., ARTHINGTON, A.H., GESSNER, M.O., KAWABATA, Z.-I., KNOWLER, D.J., LÉVÊQUE, C., NAIMAN, R.J., PRIEUR-RICHARD, A.-H., SOTO, D., STIASSNY, M.L.J. \& SULLIVAN, C.A. 2006. Freshwater biodiversity: importance, threats, status and conservation challenges. Biological Reviews, 81(2), 163-82. DOI:10.1017/S1464793105006950.

FARIAS, G. B., \& PEREIRA, G. A. 2009. Aves de Pernambuco: o estado atual do conhecimento ornitológico. Biotemas. 22(3): 1-10.

FLORA DO BRASIL 2020 EM CONSTRUÇÃO. 2018. Jardim Botânico do Rio de Janeiro. Disponível em: < http://floradobrasil.jbrj.gov.br/ > last access at: 26/07/2018).

FROESE, R. \& D. PAULY. Editors. 2018. FishBase. World Wide Web electronic publication. www.fishbase.org, version (06/2018). (last access at: 26/07/2018).

IUCN 2018. The IUCN Red List of Threatened Species. Version 2018-1. <http:// www.iucnredlist.org > . (last access at: 05/07/2018)

INSTITUTO HÓRUS DE DESENVOLVIMENTO E CONSERVAÇÃO AMBIENTAL. Base de dados nacional de espécies exóticas invasoras I3N Brasil. Florianópolis - SC. http://i3n.institutohorus.org.br/www. (last access at: $25 / 05 / 2018$ ).

JANUCHOWSKI-HARTLEY, S.R., HOLTZ, L.A., MARTINUZZI, S., MCINTYRE, P.B., RADELOFF, V.C. \& PRACHEIL, B.M. 2016. Future land use threats to range-restricted fish species in the United States. Diversity and Distributions, 22 (6), 663-671.

TELINO JÚNIOR, W. R., AZEVEDO JÚNIOR, S. M. \& LYRA NEVES, R. M. 2003. Biologia e censo de Porphyrula martinica, Gallinula chloropus e Jacana jacana em Dois Irmãos, Pernambuco, Brasil. Lundiana. 4(1), 43-49.

KASPER, K.B., FELDENS, M.J., SALVI, J. \& GRILLO, H.C.J. 2004. Estudo preliminar sobre a ecologia de Lontra longicaudis no Vale do Taquari, Sul do Brasil. Revista Brasileira Zoologia 21 (1) 65-72.
LAZZARO, X., BOUVY, M., RIBEIRO-FILHO, R.A., OLIVIERA, V.S., SALES, L.T., VASCONCELOS, A.R.M. \& MATA, M.R. 2003. Do fish regulate phytoplankton in shallow eutrophic Northeast Brazilian reservoirs? Freshwater Biology 48: 649-668. DOI:10.1046/j.1365-2427.2003.01037.x.

MAIA, L. C., MACHADO, I. C., LOPES, A. V. \& PÔRTO, K. C. 1998. Diversidade de fungos e líquens e sucessão fúngica na Reserva Ecológica de Dois Irmãos. In Reserva Ecológica de Dois Irmãos: Estudos em em Remanescente de Mata Atlântica em Área Urbana (Recife - Pernambuco Brasil) (I.C. Machado, A. V. Lopes, \& J.C. Porto, eds). Editora Universitária da UFPE, Recife, p. 85-113.

MARTINELLI, G. \& MORAES, M. A. (org) 2013. Livro vermelho da flora do Brasil. Instituto de Pesquisas Jardim Botânico do Rio de Janeiro, Rio de Janeiro.

MINISTÉRIO DO MEIO AMBIENTE (MMA). (2014). Lista Nacional Oficial de espécies da fauna ameaçadas de extinção. Diário Oficial da União.

MOURA-JUNIOR, E.G., LIMA, L.F., SILVA, S.S.L., DE PAIVA, R.M.S., FERREIRA, F.A., ZICKEL, C.S. \& POTT, A. 2013. Aquatic macrophytes of Northeastern Brazil: Checklist, richness, distribution and life forms. Check List. 9: 298-312.

MOURA-JÚNIOR, E. G., SILVA, S. S. L., LIMA, L. F., LIMA, P. B., DE ALMEIDA JR, E. B., PESSOA, L. M., SANTOS-FILHO, F.S., MEDEIROS, D.P.W., PIMENTEL, R.M.M.\& ZICKEL, C. S. 2010. Diversidade de plantas aquáticas vasculares em açudes do Parque Estadual de Dois Irmãos (PEDI), Recife-PE. Revista de Geografia 26(3): 276-293.

NASCIMENTO, P.R.F. 2009. Levantamento florístico e produtividade de macrófitas aquáticas ocorrentes em ambientes limnéticos do estado de Pernambuco - Brasil. Tese de doutorado, Universidade Federal Rural de Pernambuco, Recife.

OERTLI, B., D. AUDERSET JOYE, E. CASTELLA, R. JUGE, D. CAMBIN \& J. B. LACHAVANNE. 2002. Does size matter? The relationship between pond area and biodiversity. Biological Conservation, 104: 59-70.

PAGLIA, A.P., FONSECA, G.A.B. DA, RYLANDS, A.B., HERRMANN, G., AGUIAR, L.M.S., CHIARELlO, A.G., LEITE, Y.L.R., COSTA, L.P., SICILIANO, S., KIERULFF, M.C.M., MENDES, S.L., TAVARES V.C., MITTERMEIER, R.A. \& PATTON, J.L. 2012. Annotated Checklist of Brazilian Mammals. Edition Arlington, Conservation International. Occasional Papers in Conservation Biology, 2(6) p.76.

PEDRALLI, G. 2003. Macrófitas aquáticas como bioindicadoras da qualidade da água: alternativas para usus múltriplos de reservatórios. In Ecologia e Manejo de Macrófitas Aquáticas (S.M. Thomaz \& L.M. Bini, eds). Editora da Universidade Estadual de Maringá, Maringá, p. 171 - 188.

PELICICE, F. M. \& AGOSTINHO, A. A. (2009). Fish fauna destruction after the introduction of a non-native predator (Cichla kelberi) in a Neotropical reservoir. Biological Invasions. 11(8): 1789-1801.

PEREIRA E., SANTOS, E. M. \& RODRIGUES, M.F. 2016. Guia dos anfíbios do Parque Estadual De Dois Irmãos, Recife. Editora da UFRPE, Recife.

PEREIRA, E. N., LIRA, C. S. \& SANTOS, E. M. (2016). Ocupação, distribuição espacial e sazonal dos anfíbios anuros, em fragmento de mata atlântica. Revista Ibero-Americana de Ciências Ambientais, 7(2), 70-83.

PEREIRA, E. N. 2013. Anfíbios anuros do Parque Estadual Dois Irmãos (RecifePE) - aspectos ecológicos, representação humana e proposta pedagógica para educação ambiental. Monografia conclusão de curso, Universidade Federal Rural de Pernambuco, Recife.

PEZZINI, F.F., MELO, P.H.A., OLIVEIRA, D.M.S., AMORIM, R.X., FIGUEIREDO, F.O.G., DRUCKER, D.P., RODRIGUES, F.R.O., ZUQUIM G., SOUSA, T.E.L., COSTA, F.R.C., MAGNUSSON, W.E., SAMPAIO, A.F., LIMA, A.P., GARCIA, A.R.M., MANZATTO, A.G., NOGUEIRA, A., COSTA, C.P., BARBOSA, C.E.D.A., CASTILHO, C.B.C.V., CUNHA, C.N., FREITAS, C.G., CAVALCANTE, C.O., BRANDÃO, D.O., RODRIGUES, D.J., SANTOS, E.C.P.R., BACCARO, F.B., ISHIDA, F.Y., CARVALHO, F.A., MOULATLET, G.M., GUILLAUMET, J.-L.B., PINTO, J.L.P.V., SCHIETTI, J., VALE, J.D., BELGER, L., VERDADE, L.M., PANSONATO, M.P., NASCIMENTO, M.T., SANTOS, M.C.V., CUNHA, M.S., ARRUDA, R., BARBOSA, R.I., ROMERO, R.L., PANSINI, S. \& PIMENTEL, T.P. The Brazilian Program for Biodiversity Research (PPBio) Information System. Biodivers. Ecol. 4: 265-274. doi:10.7809/b-e.00083. 
Magalhães, K.M. et al.

PIACENTINI, V. Q., ALEIXO, A., AGNE, C. E., MAURÍCIO, G. N., PACHECO, J. F., BRAVO, G. A., BRITO, G. R. R., NAKA, L. N., OLMOS, F., POSSO, S., SILVEIRA, L. F., BETINI, G. S., CARRANO, E., FRANZ, I., LEES, A. C., LIMA, L. M., PIOLI, D., SCHUNCK, F., AMARAL, F. R., BENCKE, G. A., COHN-HAFT, M., FIGUEIREDO, L. F. A., STRAUBE, F. C. \& CESARI, E. 2015. Annotated checklist of the birds of Brazil by the Brazilian Ornithological Records Committee/Lista comentada das aves do Brasil pelo Comitê Brasileiro de Registros Ornitológicos. Revista Brasileira de Ornitologia-Brazilian Journal of Ornithology, 23(2), 90-298.

QUADROS, J. 2009. Plano de conservação da lontra neotropical (Lontra longicaudis). In Instituto Ambiental do Paraná. Planos de Conservação para Espécies de Mamíferos Ameaçados. IAP/ Projeto Paraná Biodiversidade.

RICCIARDI, A.\& RASMUSSEN, J.B. 1999. Extinction rates of North American freshwater fauna. Conservation Biology. 13 (5) 1220-1222. doi:10.1046/ j.1523-1739.1999.98380.x

ROCHA, O. 2003. Avaliação do estado do conhecimento da diversidade biológica do Brasil. MINISTÉRIO DO MEIO AMBIENTE, Brasília.

RODRIGUES, L. A.; LEUCHTENBERGER, C.; KASPER, C. B.; JUNIOR, O. C. \& SILVA, V. C. F. 2013. Avaliação do risco de extinção da Lontra neotropical Lontra longicaudis (Olfers, 1818) no Brasil. Biodiversidade Brasileira, 3(1), 216-227.

RODRIGUES, M. F., MORAES, B. L. C., MALTA, A. J. R., OLIVEIRA, M. A. O. M. C. \& MASCARENHAS-LEITE, L. M. R. 2005. Conhecimento da comunidade do Bairro de Dois Irmãos sobre a mastofauna terrestre local, e suas interferências antrópicas diretas sobre os animais. In VII Congresso Brasileiro de Ecologia. Caxambu, Minas Gerais.

SAUNDERS, D. L., MEEUWIG, J. J. \& VINCENT, A. C. J. 2002. Freshwater protected areas: strategies for conservation. Conservation Biology. 16(1): $30-41$.

SANTOS, E. M.; BARBOSA, V. N. \& CORREIA, J. S. 2017. Guia de Répteis do Parque Estadual de Dois Irmãos. Editora da Universidade Federal Rural de Pernambuco, Recife.

SANTOS, E. D., RAMEH-DE-ALBUQUERQUE, L. C., ZANOTTI, A. P., PEREIRA, E. D. N. \& DOS SANTOS, E. M. 2015a. Podocnemis expansa (Schweigger, 1812) (Reptilia, Testudines, Podocnemidae): exotic species in the state of Pernambuco, Northeast Region of Brazil. Boletim do Museu Paraense Emílio Goeldi, Ciências Naturais 10(2): 261-265.

SANTOS, E. M., SOUZA, D. T. M. T. O., SANTOS, E.; PEREIRA, E. N., CORREIA, J. M. S., RAMEH- DE- ALBUQUERQUE, L. C. \& ZANOTTI, A. 2015b. Espécies de testudines exóticos no Parque Estadual De Dois Irmãos, Recife/PE. In VII Congresso Brasileiro de Herpetologia, Gramado - Rio Grande do Sul.

SANTOS, E. M. \& SILVA, L. A. M. 1998. Anurofauna da Reserva Ecológica de Dois Irmãos. Reserva Ecológica de Dois Irmãos: Estudos em um Remanescente de Mata Atlântica em Área Urbana (Recife, Pernambuco, Brasil). Editora Universitária da Universidade Federal de Pernambuco, Recife.

SCHEFFER, M., VAN GEEST, G.J., ZIMMER, K., JEPPESEN, E., SØNDERGAARD, M., BUTLER, M.G., HANSON, M.A., DECLERCK, S. \& DE MEESTER, L. 2006. Small habitat size and isolation can promote species richness: second-order effects on biodiversity in shallow lakes 394 and ponds. Oikos 112 (1): 227-231.
SILVA, A.J., JUNIOR, C.S.M., SANTOS, F.A., SILVA, S.M.F., SILVA, T.B., MELO JUNIOR, M. \& MELO, V.L.S.A. 2019. Rotifera de reservatórios com diferentes exposições antrópicas em um fragmento protegido de mata atlântica. Oecologia Australis. 23: 333-345. 10.4257/oeco.2019.2302.11.

SILVA, P. S., PIMENTEL, G., FALCÃO, M. \& SANTOS, E.M. 2013. Distribuição espacial de anfíbios anuros no açude central do Parque Estadual de Dois Irmãos (PEDI) Recife-PE. In XIII Jornada de Ensino, Pesquisa e Extensão - JEPEX, Recife.

SILVESTRE, A.N. \& CARVALHO, P.V.B.C. 1998. Bacia do Prata: aspectos qualitativos da água. In Reserva Ecológica de Dois Irmãos: Estudo em um Remanescente de Mata Atlântica em Área Urbana (Recife-PernambucoBrasil) (I.C. Machado, A. V. Lopes, \& J.C. Porto, eds). Editora Universitária da UFPE, Recife, p. 51-64.

SIMBERLOFF, D. 2003. How much information on population biology is needed to manage introduced species? Conservation Biology 17(1): 83-92.

SOARES, C. E. A. \& ELMOOR-LOUREIRO, L. M. A. 2011. Uma atualização da lista de Cladocera Cladocera (Crustacea, Branchiopoda) do Estado de Pernambuco, Brasil. Biota Neotropica, 11(2). http://www.biotaneotropica. org.br/v11n2/pt/abstract?article+bn00711022011 (last access at: 16/08/2018)

SOUZA, D. T. M. T. O., CORREIA, J. M. S., ALBUQUERQUE, L. C. R. \& SANTOS, E.M. 2019. Record of exotic species Yellow-spotted river turtle (Podocnemis unifilis Podocnemididae) in a Conservation Unit in Northeastern Brazil. Herpetology Notes. 12: 87-89

STARLING, F., LAZZARO, X., CAVALCANTI, C. \& MOREIRA, R. 2002. Contribution of omnivorous tilapia to eutrophication of a shallow tropical reservoir: evidence from a fish kill. Freshwater Biology, 47(12): 2443-2452.

SZOLLOSI-NAGY, A., NAJLIS, P. \& BJORKLUND, G. 1998. Assessing the world's freshwater resources. Nature and Resources, 34:8-18.

THOMAS, L. \& MIDDLETON, J. 2003. Guidelines for management planning of protected areas. IUCN Gland, Switzerland and Cambridge, UK.

TRAVASSOS JUNIOR, A. M. 1993. Colonização de algas perifíticas em Eleocharis interstincta no açude do Prata. Dissertação de mestrado, Universidade Federal Rural de Pernambuco, Recife.

URBAN, M. C., SKELLY, D. K., BURCHSTED, D., PRICE, W. \& LOWRY, S. 2006. Stream communities across a rural-urban landscape gradient. Diversity and Distributions, 12(4): 337-350.

VASCONCELOS, A. C. C., ESKINAZI-LEÇA, E., PASSAVANTE, J. Z. O., LOPES-CHAMIXAES, C. B. C. B., MACHADO, I. C., LOPES, A. V. \& PÔRTO, K. C. 1998. Algas perifíticas (epífitas) dos açudes do Vale do Prata (Reserva Ecológica de Dois Irmãos). In Reserva Ecológica de Dois Irmãos: Estudo em um Remanescente de Mata Atlântica em Ảrea Urbana (Recife-Pernambuco-Brasil) (I.C. Machado, A. V. Lopes, \& J.C. Porto, eds). Editora Universitária da UFPE, Recife, p. 65-83.

VÖRÖSMARTY, C. J., MCINTYRE, P. B., GESSNER, M. O., DUDGEON, D., PRUSEVICH, A., GREEN, P., GLIDDEN, S., BUNN, S.E., SULLIVAN, C.A., LIERMANN, C.R. \& DAVIES, P. M. 2010. Global threats to human water security and river biodiversity. Nature. 467 (7315), 555.

WIKIAVES (2008) WikiAves, a Enciclopédia das Aves do Brasil. Disponível em: <http://www.wikiaves.com.br/> (last access at: 20/5/2018)

Received: 03/04/2019

Revised: $15 / 07 / 2019$

Accepted: 19/08/2019

Published online: 10/10/2019 